\title{
Intraocular inflammation as the main manifestation of Rickettsia conorii infection
}

\author{
Archimedes LD Agahan ${ }^{1,3}$ \\ Jenice Torres' \\ Graciana Fuentes-Páez' \\ Hernan Martínez-Osorio' \\ Antonio Orduña ${ }^{2}$ \\ Margarita Calonge ${ }^{\prime}$ \\ 'Ocular Immunology and Uveitis Unit, \\ Institute of Applied Ophthalmobiology \\ (IOBA), ${ }^{2}$ Microbiology Department, \\ University of Valladolid, Valladolid, \\ Spain; ${ }^{3}$ Department of Ophthalmology \\ and Visual Sciences, University of \\ the Philippines, Philippine General \\ Hospital, Manila, Philippines
}

This article was published in the following Dove Press journal:

Clinical Ophthalmology

23 September 201I

Number of times this article has been viewed
Objective: To report the clinical features and management of seven cases of intraocular inflammation caused by Rickettsia infection and review published literature.

Methods: Rickettsia conorii or Rickettsia spp. infection was diagnosed based on the following criteria: (1) positive serology according to the European Guidelines, (2) titer normalization after specific treatment, and (3) complete resolution of ophthalmic disease and accompanying symptoms after antibiotic therapy.

Results: Seven patients were referred for uveitis of unknown etiology. All came from regions where Mediterranean spotted fever is prevalent. One patient met the European guidelines criteria for Rickettsia spp. infection, while the other six cases met the criteria for $R$. conorii infection. The main symptoms were visual loss, floaters, eye redness, photophobia, and ocular pain. Predominant ophthalmic signs included vasculitis, choroiditis, vitritis, and macular edema. All patients required antibiotic treatment that resulted in the remission of the infection. Doxycycline was the first choice and the only antibiotic used to treat four patients. One patient needed ciprofloxacin as a second antibiotic after not responding to doxycycline. Two patients had doxycycline as a second antibiotic after not responding primarily to sulfonamides (which had been given after 2-3 days of doxycycline gastric intolerance); one of these patients needed ciprofloxacin as a third antibiotic.

Conclusion: Intraocular inflammation can occur as the main manifestation of Rickettsia conorii or Rickettsia spp. infection. It should be considered as a differential diagnosis for uveitis especially for patients living in countries where this infection is endemic in the world. Antibiotic treatment remains effective in the management of Rickettsia infection.

Keywords: intraocular inflammation, Mediterranean spotted fever, Rickettsia conorii, uveitis

\section{Introduction}

Mediterranean spotted fever (MSF) or boutonneuse fever is an acute systemic disease, first described in 1910 in Tunisia by Conor and Bruch. ${ }^{1}$ It is transmitted to humans by tick bites. The etiologic agent is Rickettsia conorii, a small coccobacillary intracellular bacterium belonging to the spotted fever group of the Rickettsia family. ${ }^{2}$ MSF is an endemic disease occurring during spring and summer in Asia, Africa, and Mediterranean countries. ${ }^{3}$ The pathophysiology of $R$. conorii infection is characterized by vascular invasion causing injury and tissue necrosis. ${ }^{4}$ Endothelial cells are the organism's main target. ${ }^{4}$

In addition to general malaise, the clinical symptoms of Rickettsia infection include the triad of fever, skin rash, and headaches. There are many reports on the systemic manifestations of MSF, but reports on the ophthalmic presentations of this disease
Correspondence: Margarita Calonge IOBA, Universidad de Valladolid,

Campus Miguel Delibes, Paseo de Belén

17, Valladolid E-470I I, Spain

$\mathrm{Tel}+34983 \quad 184750$

$\mathrm{Fax}+34983184762$

Email calonge@ioba.med.uva.es 
are scarce. The existing reports are short communications or correspondence and describe ocular manifestations that include conjunctivitis, keratitis, anterior uveitis, panuveitis, retinitis, retinal vascular occlusions, retinal vasculitis, intraretinal hemorrhages, macular edema, macular star, optic disc edema, optic neuritis, and multiple evanescent white dot syndrome-like lesions. ${ }^{1,2,5-22}$

Guidelines for the diagnosis of tick-borne bacterial diseases in Europe have been reported, and consequently serologic antibody titers for the diagnosis of $R$. conorii and other Rickettsia spp. infections have been standardized. ${ }^{23}$ We describe the largest reported series to date of $R$. conorii and Rickettsia spp. infection with uveitis as the predominant manifestation.

\section{Materials and methods}

Seven patients diagnosed with uveitis due to Rickettsia infection and cared for at the Ocular Immunology and Uveitis Unit of IOBA, University of Valladolid, Spain, between May 1999 and March 2006, were identified from a database. We performed the retrospective portion of this study by reviewing clinical histories. Beginning in March 2005, patients were prospectively followed. The Ethics Committee of the University of Valladolid approved this study. Each patient completed a detailed uveitis questionnaire at the initial visit. Comprehensive family, personal, and ophthalmic histories were obtained. A complete ocular examination was performed at every visit, including best-corrected visual acuity, slit-lamp examination, tonometry, and ophthalmoscopy. Fluorescein angiography or other tests were performed when considered necessary. Uveitis was classified as anterior, intermediate, posterior, or panuveitis. ${ }^{24}$ Demographic data were recorded to include age, race, gender, city of origin, systemic signs and symptoms, previous treatments, serologies, and treatment initiated at our institution. We also recorded the delay to diagnosis as the elapsed time between initial symptoms and our diagnosis and the follow-up time as the elapse period between diagnosis of rickettsiosis and last visit. Additionally, the average time to achieve therapeutic success was recorded as the elapsed time between last antibiotic treatment and the last visit. Clinical findings and follow-up results were recorded. Ocular symptoms and signs were recorded by eye.

According to the guidelines for the diagnosis of tickborne bacterial diseases in Europe, ${ }^{23}$ diagnostic criteria for $R$. conorii infection in suspected cases of MSF are IgG titers $\geq 128$ and/or IgM titers $\geq 64$ as determined by serum immunofluorescence. IgG titers $\geq 64$ and/or IgM titers $\geq 32$ are considered indicative of infection by other $R$. spp. ${ }^{23}$ We considered that to diagnose a uveitis case as caused by Rickettsia, the three following criteria had to be met: (1) positive serology by ELISA testing according to the European guidelines as stated above, (2) normalization of antibody titers 3 months after specific antibiotic treatment, and (3) complete resolution of ophthalmic disease and accompanying symptoms. This last criterion means that diagnosed patients had to be cured (absence of symptoms, no inflammatory cells, and disappearance of all active signs of inflammation) with no further recurrence. The patient was considered "cured" when titers became negative and inflammation disappeared and did not recur.

\section{Results}

Demographic and extraocular findings are reported in Table 1, whereas variables concerning ophthalmic involvement are shown in Table 2. A total of ten eyes of seven Caucasian subjects, four males and three females, $39.1 \pm 16.0$ years old (mean $\pm \mathrm{SD}$; range: 8-54; median: 43 years) were included in this study. The mean follow-up time was $46.4 \pm 26.9$ months (range: 12-84 months; median: 40 months). The mean follow-up of elapsed time between the last successful antibiotic treatment and last visit was $35.2 \pm 29.6$ months (range: 6-72 months; median: 20 months). Six patients came from Extremadura in the southwest region of Spain and one from Andalucia in the southernmost region.

The main symptoms included loss of vision in seven eyes and floaters in four eyes. Less frequently, the patients presented with redness, photophobia, and pain. Ophthalmic examinations revealed vitritis in nine eyes, macular edema in five eyes, and vasculitis, the predominant feature as expected, in six eyes. The vasculitis was venous and focal in nature with sheathing and mild leakage in all cases, except in Case 5 , where phlebitis was more diffuse. Other ophthalmic signs included central retinal vein thrombosis in Case 5 (Figure 1A and $1 \mathrm{~B}$ ), due to venous inflammation, focal choroiditis, multifocal choroiditis, focal keratopathy, anterior chamber cells, posterior synechiae, retinal hemorrhages, and papillitis. Four cases were unilateral and three were bilateral. All patients had frequent contact with dogs and two patients were aware of insect bites, including one by tick and one by flea. One of the two patients recalled a cutaneous lesion compatible with erythema migrans after a tick bite. Three patients described transient extraocular manifestations of arthralgias and fever that had already disappeared before their first visit with us.

Our choice of antibiotic treatment followed the guidelines proposed by Raoult et al. ${ }^{25}$ One antibiotic course of treatment (doxycycline $100 \mathrm{mg} / 12$ hours for 8-10 weeks) was sufficient in four patients (Cases 1, 2, 3, and 5). Two courses were 
Table I Patient demographics and extraocular findings

\begin{tabular}{|c|c|c|c|c|c|c|c|c|c|}
\hline \multirow[t]{2}{*}{ Case } & \multirow[t]{2}{*}{$\begin{array}{l}\text { Agel } \\
\text { sex }\end{array}$} & \multirow{2}{*}{$\begin{array}{l}\text { Region of } \\
\text { origin in } \\
\text { Spain }\end{array}$} & \multicolumn{2}{|c|}{$\begin{array}{l}\text { Anti-R. conorii titers } \\
\text { IgG; IgM (ELISA) }\end{array}$} & \multirow[t]{2}{*}{$\begin{array}{l}\text { Extraocular } \\
\text { findings }\end{array}$} & \multirow[t]{2}{*}{$\begin{array}{l}\text { Total FU } \\
\text { (months) }\end{array}$} & \multirow{2}{*}{$\begin{array}{l}\text { Diagnosis } \\
\text { delay } \\
\text { (months) }\end{array}$} & \multirow[t]{2}{*}{$\begin{array}{l}\text { Antibiotic } \\
\text { treatment }\end{array}$} & \multirow{2}{*}{$\begin{array}{l}\text { Elapsed time } \\
\text { of last antibiotic } \\
\text { treatment to } \\
\text { last FU (months) }\end{array}$} \\
\hline & & & $\begin{array}{l}\text { Pre- } \\
\text { antibiotic }\end{array}$ & $\begin{array}{l}3 \text { months } \\
\text { post- } \\
\text { antibiotic }\end{array}$ & & & & & \\
\hline I & $33 / M$ & $\begin{array}{l}\text { Extremadura } \\
\text { (Cáceres) }\end{array}$ & $\begin{array}{l}\mathrm{I} / 40 \\
\mathrm{I} / 80\end{array}$ & $\begin{array}{l}\text { Negative; } \\
\text { Negative }\end{array}$ & None & 84 & 11 & Doxycycline & 72 \\
\hline 2 & $8 / M$ & $\begin{array}{l}\text { Extremadura } \\
\text { (Cáceres) }\end{array}$ & $\begin{array}{l}\mathrm{I} / 40 \\
\mathrm{I} / 40\end{array}$ & $\begin{array}{l}\text { Negative; } \\
\text { Negative }\end{array}$ & $\begin{array}{l}\text { Arthralgia } \\
\text { Fever }\end{array}$ & 75 & 2 & Doxycycline & 72 \\
\hline 3 & $43 / M$ & $\begin{array}{l}\text { Andalucía } \\
\text { (Almería) }\end{array}$ & $\begin{array}{l}1 / 160 \\
1 / 40\end{array}$ & $\begin{array}{l}\text { Negative; } \\
\text { Negative }\end{array}$ & None & 59 & 3 & Doxycycline & 54 \\
\hline 4 & $54 / F$ & $\begin{array}{l}\text { Extremadura } \\
\text { (Cáceres) }\end{array}$ & $\begin{array}{l}\text { I/I60; } \\
1 / 80\end{array}$ & $\begin{array}{l}\text { Negative; } \\
\text { Negative }\end{array}$ & None & 40 & 3 & $\begin{array}{l}\text { TMP-SFX } \\
\text { doxycycline } \\
\text { ciprofloxacin }\end{array}$ & 12 \\
\hline 5 & $35 / M$ & $\begin{array}{l}\text { Extremadura } \\
\text { (Cáceres) }\end{array}$ & $\begin{array}{l}1 / 80 \\
1 / 80\end{array}$ & $\begin{array}{l}\text { Negative; } \\
\text { Negative }\end{array}$ & $\begin{array}{l}\text { Erythema migrans } \\
\text { after tick bite }\end{array}$ & 30 & 2 & Doxycycline & 20 \\
\hline 6 & $5 \mathrm{I} / \mathrm{F}$ & $\begin{array}{l}\text { Extremadura } \\
\text { (Badajoz) }\end{array}$ & $\begin{array}{l}1 / 320 \\
1 / 20\end{array}$ & $\begin{array}{l}\text { Negative; } \\
\text { Negative }\end{array}$ & Arthralgia & 25 & 1 & $\begin{array}{l}\text { TMP-SFX } \\
\text { doxycycline }\end{array}$ & 11 \\
\hline 7 & $50 / F$ & $\begin{array}{l}\text { Extremadura } \\
\text { (Badajoz) }\end{array}$ & $\begin{array}{l}1 / 40 \\
1 / 160\end{array}$ & $\begin{array}{l}\text { Negative; } \\
\text { Negative }\end{array}$ & $\begin{array}{l}\text { Arthralgia } \\
\text { Flea bites }\end{array}$ & 12 & 2 & $\begin{array}{l}\text { Doxycycline } \\
\text { ciprofloxacin }\end{array}$ & 16 \\
\hline
\end{tabular}

Note: TMP-SFX combination was given 2-3 days after patients reported gastric complaints with doxycycline. After therapeutic failure, doxycyline was given again with gastric precaution to complete the treatment regimen.

Abbreviations: FU, follow-up; TMP-SFX, trimethoprim-sulfamethoxazole.

required in three patients (Cases 6 and 7), and three antibiotic courses were required for remission in one patient (Case 4). Doxycycline was always our first choice and was enough to cure the infection in four patients. Two more patients, however (Cases 4 and 6) reported gastric complaints after 2-3 days on doxycycline and we switched them to the fixed combination, $80 \mathrm{mg}$ trimethoprim-400 $\mathrm{mg}$ sulfamethoxazole/12 hours for 8-10 weeks, following advice of the referring internist. After failure of this antibiotic, they were given doxycycline again, this time with strict gastric protection; although still some gastric complaints were present, patients were able to complete the entire treatment. One of them (Case 6) was cured, and the other one (Case 4) required a third treatment (Figure 2A to 2D) with $750 \mathrm{mg} / 12$ hours for 10 days of oral ciprofloxacin. Serology tests were negative in all patients when re-tested 3 and 6 months after the end of the antibiotic therapy.

\section{Discussion}

Rickettsia species are obligate intracellular organisms, with vascular tropism, that survive in mammalian reservoirs and insect vectors. The taxonomy of the Rickettsia genus has undergone significant reorganization in the last decade. Humans are usually incidental hosts, who are infected by the bite during feeding of contaminated arthropods such as ticks, mites, fleas, and lice. ${ }^{3}$ These zoonoses, caused by Rickettsia species, can be classified into three groups: (1) rickettsiosis due to bacteria of the genus Rickettsia, including the spotted fever group (SFG) and the typhus group Rickettsiae; R. rickettsii is responsible for rocky mountain spotted fever (RMSF), $R$. conorii for MSF; (2) ehrlichioses and anaplasmoses, due to bacteria within the family Anaplasmataceae; and (3) scrub typhus, due to Orientia tsutsugamushi. ${ }^{23}$

Rickettsioses from the SFG, perhaps the best known, are characterized by development of tache noir at the site of the arthropod bite, high fever, myalgia, headaches, and occasional gastrointestinal and neurological signs. RMSF is an important human rickettsiosis in the United States, but other rickettsial spotted fevers are encountered mostly in other continents. ${ }^{26,27}$ For RMSF, the systemic disease can be accompanied by bilateral optic disk edema, cottonwool spots, and tortuous retinal veins. ${ }^{28}$ In other cases with no systemic manifestations, RMSF can present as keratic precipitates, anterior chamber and vitreous cells, optic disc edema, retinal hemorrhages, retinal arteriolar sheathing, and macular star. ${ }^{29}$

The dog tick Rhipicephalus sangineus, which inoculates $R$. conorii into the skin while feeding, transmits MSF. Patients present with a characteristic tache noir in $50 \%-75 \%$ of cases and systemic disease one week after contact. They have a good prognosis. ${ }^{26}$ The pathophysiologic hallmark is vascular endothelial cell invasion by the organism, causing endothelial injury and tissue necrosis. It is an endemic disease in Mediterranean countries, including Spain, with reported cases in the regions of Extremadura, Andalucia, Castilla y León, and the east coast. ${ }^{30-32} R$. conorii, $R$. mongolotimonae, 
Table 2 Description of ocular pathology and results at end of follow-up

\begin{tabular}{|c|c|c|c|c|c|c|c|c|}
\hline Case & Eye & $\begin{array}{l}\text { Initial } \\
\text { (referral) } \\
\text { diagnosis }\end{array}$ & $\begin{array}{l}\text { Ocular } \\
\text { symptoms }\end{array}$ & $\begin{array}{l}\text { Type of } \\
\text { uveitis* }\end{array}$ & $\begin{array}{l}\text { Pathologic ocular } \\
\text { signs at first visit** }\end{array}$ & $\begin{array}{l}\text { Pathologic ocular } \\
\text { signs at end of FU/ } \\
\text { (time to reach clinical } \\
\text { remission after } \\
\text { antibiotic treatment)* }\end{array}$ & $\begin{array}{l}\text { BCVA at } \\
\text { end of } \\
\text { FU/reason } \\
\text { for visual loss }\end{array}$ & $\begin{array}{l}\text { Worst } \\
\text { BCVA } \\
\text { on FU }\end{array}$ \\
\hline I & OS & $\begin{array}{l}\text { Uveitis } \\
\text { due to } \\
\text { toxoplasmosis }\end{array}$ & $\begin{array}{l}\text { Loss of vision } \\
\text { Floaters }\end{array}$ & Posterior & $\begin{array}{l}+ \text { I Vitritis } \\
\text { Vasculitis } \\
\text { Choroiditis } \\
\text { Retinal hemorrhages }\end{array}$ & $\begin{array}{l}\text { Peripheral retinal vessel } \\
\text { attenuation } \\
\text { Foveal ischemia } \\
\text { (12 weeks) }\end{array}$ & $\begin{array}{l}0.100 \\
\text { Foveal ischemia }\end{array}$ & 0.100 \\
\hline 2 & OD & $\begin{array}{l}\text { Idiopathic } \\
\text { panuveitis }\end{array}$ & Asymptomatic & Posterior & $+I$ Vitritis & $\begin{array}{l}\text { None } \\
(4 \text { weeks })\end{array}$ & 1.000 & 0.900 \\
\hline & OS & $\begin{array}{l}\text { Idiopathic } \\
\text { panuveitis }\end{array}$ & $\begin{array}{l}\text { Loss of vision } \\
\text { Redness } \\
\text { Photophobia }\end{array}$ & Panuveitis & $\begin{array}{l}+2 \text { Anterior } \\
\text { chamber cells } \\
\text { Posterior synechiae } \\
+2 \text { Vitritis } \\
\text { Retinitis } \\
\text { Diffuse macular } \\
\text { edema }\end{array}$ & $\begin{array}{l}\text { Subtle retinal pigment } \\
\text { epithelial changes } \\
\text { (1 } 2 \text { weeks) }\end{array}$ & 1.000 & 0.500 \\
\hline 3 & OD & $\begin{array}{l}\text { Idiopathic } \\
\text { uveitis }\end{array}$ & $\begin{array}{l}\text { Loss of vision } \\
\text { Floaters }\end{array}$ & Posterior & Sub-foveal lesion & $\begin{array}{l}\text { Foveal scar } \\
\text { (12 weeks) }\end{array}$ & $\begin{array}{l}0.500 \\
\text { Foveal scar, } \\
\text { cataract }\end{array}$ & 0.500 \\
\hline 4 & OD & $\begin{array}{l}\text { Idiopathic } \\
\text { uveitis }\end{array}$ & Floaters & Posterior & $\begin{array}{l}+I \text { Vitritis } \\
\text { Vasculitis } \\
\text { Choroiditis }\end{array}$ & $\begin{array}{l}\text { None } \\
\text { ( } 8 \text { weeks after } \\
3 \text { rd antibiotic; } \\
6 \text { months after } \\
\text { Ist antibiotic) }\end{array}$ & 1.000 & 0.800 \\
\hline & OS & $\begin{array}{l}\text { Idiopathic } \\
\text { uveitis }\end{array}$ & Floaters & Posterior & $\begin{array}{l}\text { +I Vitritis } \\
\text { Vasculitis } \\
\text { Choroiditis } \\
\text { Macular edema }\end{array}$ & $\begin{array}{l}\text { None } \\
\text { ( } 8 \text { weeks after } \\
3 \text { rd antibiotic; } \\
6 \text { months after } \\
\text { Ist antibiotic) }\end{array}$ & 1.000 & 0.300 \\
\hline 5 & OD & $\begin{array}{l}\text { Idiopathic } \\
\text { retinal central } \\
\text { vein thrombosis }\end{array}$ & Loss of vision & Posterior & $\begin{array}{l}+2 \text { Vitritis } \\
\text { Vasculitis (phlebitis) } \\
\text { Retinal venous } \\
\text { tortuosity } \\
\text { Retinal hemorrhages } \\
\text { Macular edema }\end{array}$ & $\begin{array}{l}\text { None } \\
\text { (8 weeks) }\end{array}$ & 1.000 & 0.400 \\
\hline 6 & OD & $\begin{array}{l}\text { Idiopathic } \\
\text { intermediate } \\
\text { uveitis }\end{array}$ & $\begin{array}{l}\text { Redness } \\
\text { Pain } \\
\text { Blurred vision }\end{array}$ & Panuveitis & $\begin{array}{l}\text { Anterior chamber } \\
\text { cells } \\
\text { Posterior synechiae } \\
+ \text { I Vitritis } \\
\text { Vitreous exudates } \\
\text { Retinal hemorrhages }\end{array}$ & $\begin{array}{l}\text { None } \\
\text { (8 weeks after } \\
\text { 2nd antibiotic; } \\
4 \text { months after } \\
\text { Ist antibiotic) }\end{array}$ & 1.000 & 0.800 \\
\hline 7 & OD & Panuveitis VKH & Loss of vision & Posterior & $\begin{array}{l}+2 \text { Vitritis } \\
\text { Vasculitis } \\
\text { Choroiditis } \\
\text { Macular edema }\end{array}$ & $\begin{array}{l}\text { Focal choroidal scars } \\
\text { Vascular attenuation } \\
\text { Chronic macular edema } \\
\text { ( } 4 \text { weeks after } \\
\text { 2nd antibiotic; } \\
3 \text { months after } \\
\text { I st antibiotic) }\end{array}$ & $\begin{array}{l}0.200 \\
\text { Chronic macular } \\
\text { edema } \\
\text { Cataract }\end{array}$ & 0.100 \\
\hline & OS & Panuveitis VKH & Loss of vision & Posterior & $\begin{array}{l}+2 \text { Vitritis } \\
\text { Vasculitis } \\
\text { Disseminated } \\
\text { choroiditis } \\
\text { Focal nodules } \\
\text { Macular edema }\end{array}$ & $\begin{array}{l}\text { Focal choroidal scars } \\
\text { Vascular attenuation } \\
\text { Chronic macular edema } \\
\text { (4 weeks after } \\
\text { 2nd antibiotic; } \\
4 \text { months after } \\
\text { Ist antibiotic) }\end{array}$ & $\begin{array}{l}0.300 \\
\text { Chronic macular } \\
\text { edema } \\
\text { Cataract }\end{array}$ & 0.160 \\
\hline
\end{tabular}

Notes: *Uveitis classification according to anatomic location, ${ }^{24}{ }^{* *}$ Grading of anterior chamber cells and vitreous cells (vitritis) according to SUN working group. ${ }^{24}$ Abbreviations: OD, right eye; OS, left eye; OU, both eyes; BCVA, best corrected visual acuity; FU, follow-up; VKH, Vogt-Koyanagi-Harada. 


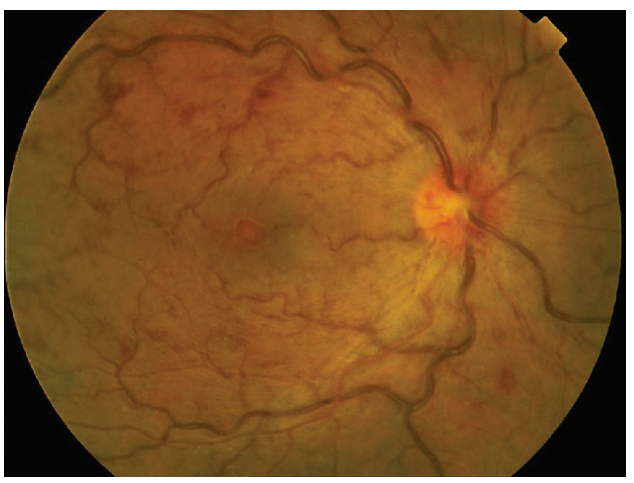

Figure I (A) Case 5. Fundus photo of the right eye shows a hyperemic disc with slightly indistinct borders especially nasally. The arteries are attenuated and the veins exhibit severe dilation and tortuosity with focal constrictions at areas of arterio-venous crossings. The posterior pole shows multiple intraretinal hemorrhages and cottonwoo spots and retinal thickening. The perifoveal vessels are also dilated and tortuous and the foveal reflex is dull. There is a white-centered hemorrhage at the fovea.

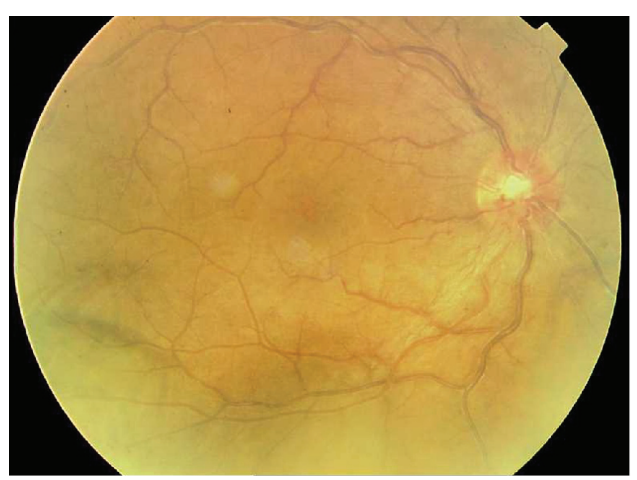

Figure I (B) Case 5. After treatment with sulfonamides and doxycycline, fundus photo shows that disc vessels are still dilated, but with distinct disc borders. There is marked decrease in vessel tortuosity and dilation. There is also an evident decrease in retinal edema and hemorrhages as compared to Figure IA.

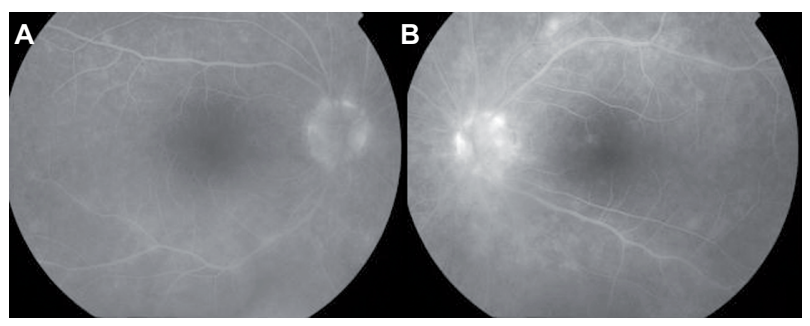

Figure 2 (A and B) Case 4. Angiogram of both eyes shows papillary, peri-papillary, and choroidal fluorescence along the superior and inferior arcades. The macula area of the left eye also shows staining along the superior peri-foveal region.

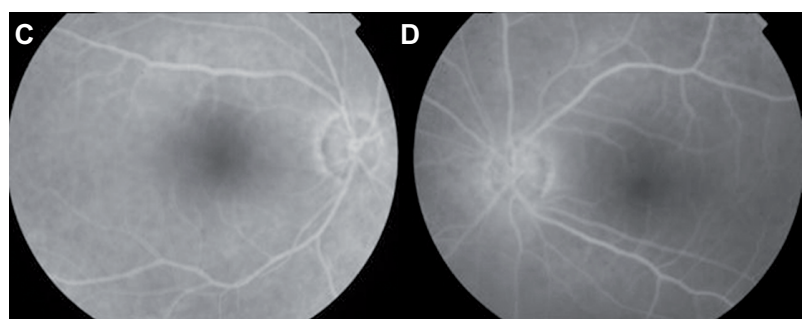

Figure 2 (C and D) Case 4. After treatment with sulfonamides, doxycycline, and ciprofloxacin, the angiogram of both eyes show normal disc fluorescence. There is no choroidal staining and no angiographic evidence of macular edema.
R. slovaca, and $R$. helvetica are the species reported in these areas. ${ }^{32}$ The last two have been associated with atypical MSF, without exanthem. ${ }^{32}$

All our patients were originally from the regions of Extremadura and Andalucia, where MSF is endemic. Most of our patients could not remember a history of insect bites, but could not deny it either. In general, $73 \%$ of patients deny having a history of tick bite, which agrees with our series, where only two patients reported insect bites. $^{32}$

Although most of our patients had no typical systemic manifestations of MSF, they did have positive serology for $R$. conorii or Rickettsia spp. infection. Cases 2, 6, and 7 had a previous history of arthralgias, which can be caused by these or other entities. In Case 2, the child's uveitis (Figure 3A to 3C) was diagnosed 3 months before a reported fever episode and appearance of a hyperemic papule. He had IgM titers of $1 / 40$, which met European criteria for Rickettsia spp. infection. ${ }^{23}$ All individuals in this series except Case 2 had IgG and/or IgM levels that met European criteria for $R$. conorii infection. ${ }^{23}$

Ocular involvement in MSF commonly occurs as vasculitis $(55.9 \%)$, choroiditis $(16.7 \%)$, serous retinal detachment $(5 \%)$, cystoid macular edema (1.7\%), and others. ${ }^{15,26,32}$ Keratitis, oculoglandular syndrome, endogenous panuveitis, vitreous hemorrhage, panuveitis with occlusive vasculitis, and chorioretinitis have also been reported..$^{8,9,12,16,33,34}$ Our patients had choroiditis, vasculitis, central retinal vein occlusion,

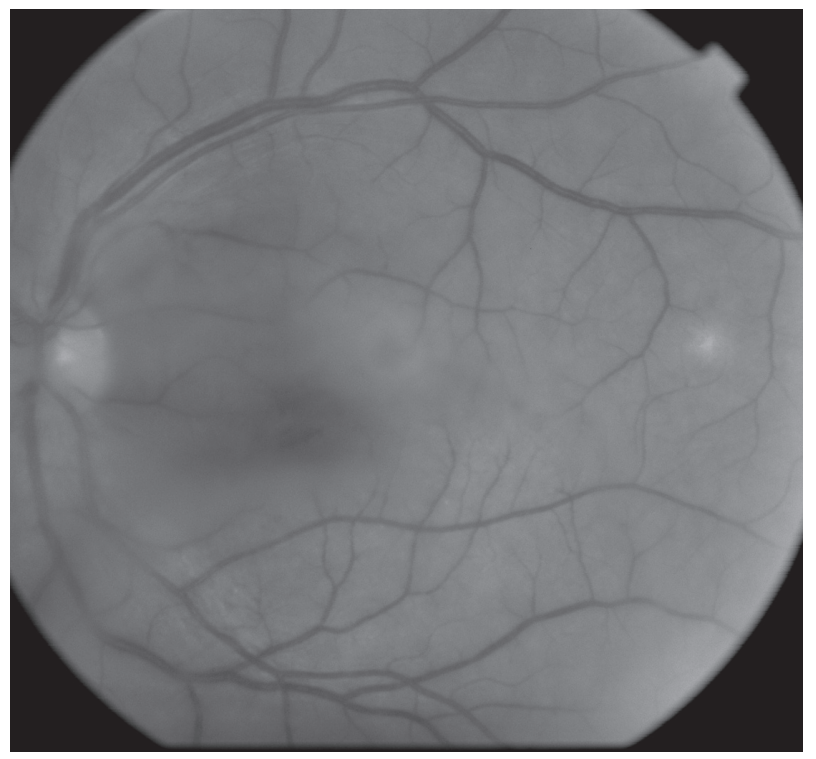

Figure 3 (A) Case 2. Angiogram of the left eye shows masking of the retinal, choiroidal, and disc fluorescence, which is due to vitreous haze (vitritis). The veins are slightly dilated with simultaneous laminar filling of the superior and inferior temporal arcades. The perifoveal vessels appear dilated. 


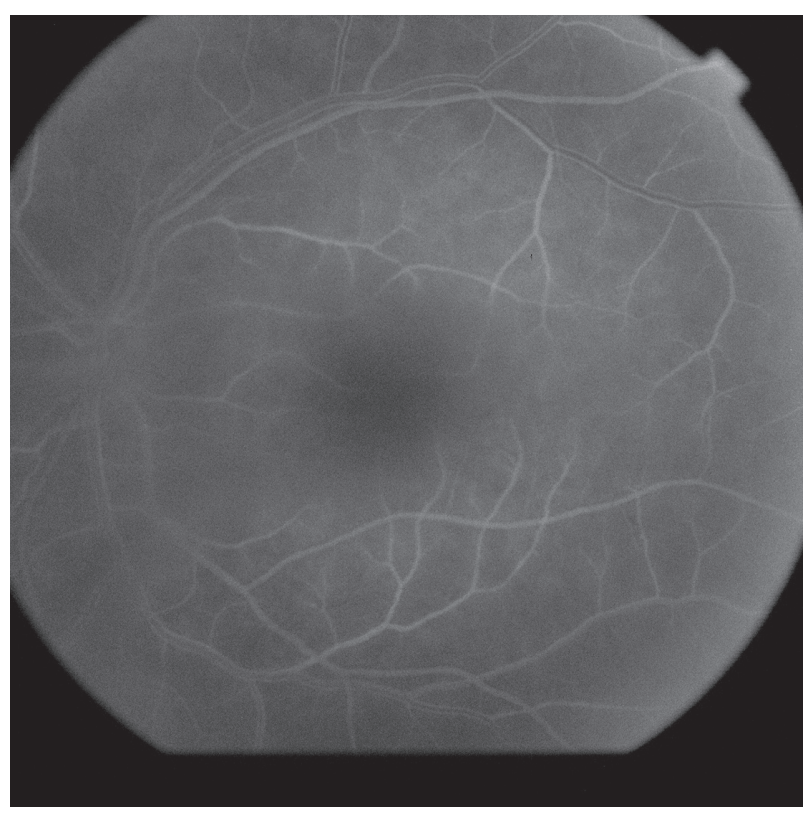

Figure 3 (B) Case 2. After treatment with doxycycline, angiogram shows less masking due to vitreous haze. There are no choroidal hyperflourescence and the perifoveal vessels appear non-dilated.

macular edema, retinal pigment epithelium detachment, bilateral choroiditis, and iridocyclitis (Figure 3C).

Case 5 had been referred to us because of central retinal vein occlusion. As far as we are aware, only Bonnet et al, in 1969, previously reported a pure ocular $R$. conorii infection in a 23-year-old grave-digger from Grenoble, who had recurrent bilateral vitreous hemorrhage due to retinal branch vein occlusion. ${ }^{33}$ This reported patient reached titers of 1/160 which normalized after the first antibiotic treatment. However, vitreous hemorrhage recurred while showing an impressive $R$. conorii titer elevation of $1 / 10,240$, which required a second intravenous terramycin treatment. Titers

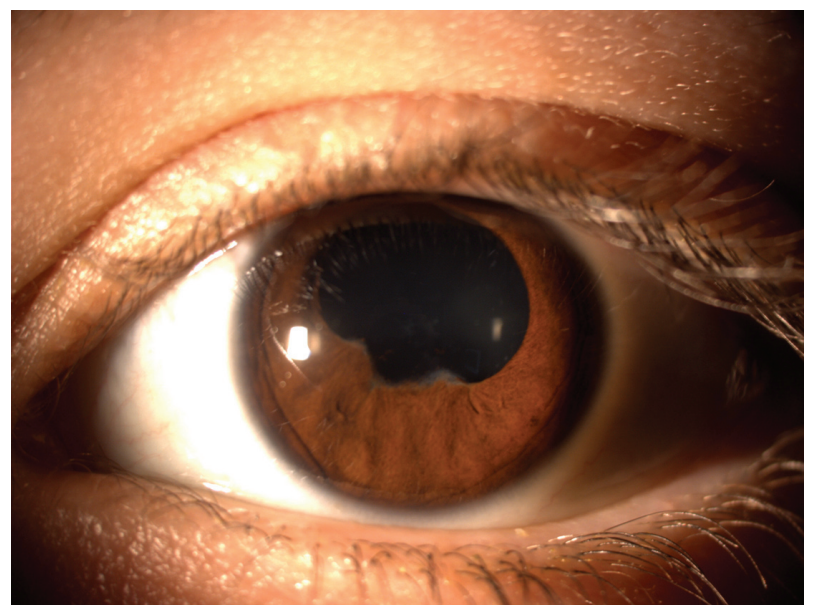

Figure 3 (C) Case 2. Anterior segment photo showing posterior synechiae in the left eye of the patient following severe anterior iridocyclitis. eventually decreased to $1 / 640 .{ }^{33}$ The patient denied contact with animals or tick bite, like some of our patients. It is important to note the lack of antibodies to other Rickettsiae at the time Bonnet's article was published, thus it is possible that any of the spotted fever group Rickettsia could have caused those findings. ${ }^{33}$

In Case 4, birdshot choroidopathy was diagnosed after clinical diagnosis and being positive with HLA-A29. However the patient did not improve after immunosuppressive therapy and had concomitant high IgG anti- $R$. conorii titers. Ocular inflammation improved and $\operatorname{IgM}$ and $\operatorname{IgG}$ anti-R . conorii titers decreased after three antibiotic courses, thus supporting our diagnosis of $R$. conorii infection. Cross reactivity with the HLA-A29 antigen has previously been considered in similar cases of birdshot choroidopathy with B. burgdorferi and Coxiella burnetti, formerly classified as a member of the order Rickettsiales, ${ }^{23}$ but not with $R$. conorii. ${ }^{35,36}$ The hypothesis of molecular mimicry has been proposed to explain the link between Gram negative bacteria and HLAB27 in the pathogenesis of ankylosing spondylitis. ${ }^{37}$ This could explain the association between tickborne bacteria, like R. conorii, C. burnetti, and B. burgdorferi, and HLA-A29 in the pathogenesis of birdshot choroidopathy. However this patient came from an area where rickettsiosis is endemic. Further, she showed high titers of anti-R. conorii IgM and $\mathrm{IgG}$, which would argue against possible cross reactivity.

Since pure ocular rickettsiosis has already been reported for $R$. conorii, we believe all cases, except Case 2, represent $R$. conorii infection limited to the eye. They all had ocular inflammation and positive anti-R. conorii $\operatorname{IgG}$ and/or IgM titers that are compatible with European criteria for $R$. conorii infection and which decreased after antibiotic treatment.

Based on the clinical and serologic progress of these seven rare cases, they epitomize uveitis by spotted fever group Rickettsias as the main manifestation of the disease. The fact that most patients came from known endemic areas led us to conclude that $R$. conorii should be always considered as a cause of uveitis in Spain and most likely in other Mediterranean countries. Although $R$. conorii was not reported as a common cause in a recent study on uveitis patterns in various geographic regions, we believe this bacterium and related species should be included in the work-up of patients with uveitis who live in endemic areas. $^{38}$

\section{Acknowledgments}

The authors expresss their appreciation to Dr JM Guerra Campos and Dr Bolivia Vera for referring patients to IOBA. 


\section{Disclosure}

Hernan Martinez-Osorio and Graciana Fuentes-Paez were supported by a grant from the Carolina Foundation, Ministry of Foreign Affairs, Spain. Archimedes LD Agahan was supported by a scholarship grant from the Agencia Española de Cooperacion Internacional (AECI), Ministry of Foreign Affairs, Spain.

\section{References}

1. Conor A, Bruch A. A fever with skin rash in Tunisia. Bull Soc Pathol Exot. 1910;3:492-496.

2. Jemni L, Hamouda H, Chakroun M, et al. Mediterranean spotted fever in central Tunisia. J Travel Med. 1994;1:106-108.

3. Parola P, Raoult D. Ticks and tickborne bacterial diseases in humans: an emerging infectious threat. Clin Infect Dis. 2001;32:897-928.

4. Bazin R. Rickettsia diseases. In: Foster CS, Vitale AT, editors. Diagnosis and treatment of uveitis. Philadelphia, PA: WB Saunders Co; 2002 : 297-304.

5. Sexton DJ, Dwyer B, Kemp R, et al. Spotted fever group Rickettsial infections in Australia. Rev Infect Dis. 1991;13:876-886.

6. Palau LA, Pankey GA. Mediterranean spotted fever in travelers from the United Stated. J Travel Med. 1997;4:179-182.

7. Font-Creus B, Bella-Cueto F, Espejo-Arenas E, et al. Mediterranean spotted fever: a cooperative study of 227 cases. Rev Infect Dis. 1985; 7: 635-642.

8. Alió J, Ruiz-Beltran R, Herrera I, et al. Rickettsial keratitis in a case of Mediterranean spotted fever. Eur J Ophthalmol. 1992;2:41-43.

9. Pinna A, Sotgiu M, Carta F, et al. Oculoglandular syndrome in Mediterranean spotted fever acquired through the eye. Br JOphthalmol. 1997;81:168.

10. Rizo AE, Muniz O, Auladell C, et al. A case of bilateral uveitis secondary to mediterranean spotted fever. Clin Infect Dis. 1992;14:624-625.

11. Esgin H, Akata F. Bilateral multiple retinal hiperfluorescent dots in a presumed Rickettsia conorii infection. Retina. 2001;21:535-537.

12. Pinna A, Sechi LA, Serru A, et al. Endogenous panuveitis in patient with Rickettsia conorii infection. Acta Ophthalmol Scand. 2000;78: 608-609.

13. Mendivil A, Cuartero V. Endogenous endophthalmitis caused by Rickettsia conorii. Acta Ophthalmol Scand. 1998;76:121-122.

14. Granel B, Serratrice J, Rey J, et al. Impaired visual acuity in Mediterranean spotted fever. Press Med. 2001;30:859.

15. Alió J, Ruiz-Beltran R, Herrero-Herrero JI, et al. Retinal manifestations of Mediterranean spotted fever. Ophthalmologica. 1987;195:31-37.

16. Bloch-Michel E, Guinnepain MT, Edlinger E, et al. Mediterranean spotted fever: apropos of the physiopathology of uveal manifestations. Bull Mem Soc Fr Ophthalmol. 1983;95:566-570.

17. François J. Rickettsiae in ophthalmology. Ophthalmologica. 1968;156: 459-472.

18. Verdot S, Estavoyer JM, Prost F, et al. Ocular involvement at the acute stage of Mediterranean spotted fever. Bull Soc Ophthalmol Fr. 1986;86: 429-431.
19. Paufique L, Bonnet M, Lequin, et al. Retinal vacular thromboses and rickettsioses. Bull Soc Ophthalmol Fr. 1964;64:410-415.

20. Rivaud C, Carrica A, Chanut G, et al. Early retinal manifestations of Mediterranean spotted fever. Apropos of 2 cases. Bull Soc Ophthamol Fr. 1980;80:961-963.

21. Adan A, Lopez-Soto A, Moser C, et al. Use of steroids and heparin to treat retinal arterial occlusion in Mediterranean spotted fever. $J$ Infect Dis. 1988;158:1139-1140.

22. Castanet J, Costet C, Dubois D, et al. Optic neuropathy secondary to Mediterranean spotted fever. Presse Med. 1988;17:439-440.

23. Brouqui P, Bacellar F, Baranton G; ESCMID Study Group on Coxiella, Anaplasma, Rickettsia and Bartonella; European Network for Surveillance of Tick-Borne Diseases. Guidelines for the diagnosis of tick-borne bacterial diseases in Europe. Clin Microbiol Infect. 2004;10: 1108-1132.

24. Jabs DA, Nussenblatt RB, Rosenbaum JT; Standardization of Uveitis Nomenclature (SUN) Working Group. Standardization of uveitis nomenclature for reporting clinical data. Results of the first international workshop. Am J Ophthalmol. 2005;140:509-516.

25. Raoult D, Drancourt M. Antibmicrobial therapy of rickettsial diseases. Antimicrob Agents Chemother. 1991;35(12):2457-2462.

26. Parola P, Davoust B, Raoult D. Tick-and flea-borne rickettsial emerging zoonoses. Vet Res. 2005;36:469-492.

27. Khairallah M, Ladjimi A, Chakroun M, et al. Posterior segment manifestations of Rickettsia conorii infection. Ophthalmology, 2004; 111:529-534.

28. Smith TW, Burton TC. The retinal manifestations of rocky mountain spotted fever. Am J Ophthalmol. 1977;84:259-262.

29. Vaphiades MS. Rocky mountain spotted fever as a cause of macular star figure. J Neuroophthalmol. 2003;23:276-278.

30. Cardeñosa N, Roux V, Font B, et al. Short report: isolation and identification of two spotted fever group Rickettsial strains from patients in Catalonia, Spain. Am J Trop Med Hyg. 2000;62:142-144.

31. Delgado S, Carmenes P. Canine seroprevalence of Rickettsia conorii infection (Mediterranean spotted fever) in Castilla y Leon (northwest Spain). Eur J Epidemiol. 1995;11:597-600.

32. Bartolomé J, Lorente S, Hernandez-Perez N, et al. Clinical and epidemiological study of spotted fever group rickettsiosis in Albacete, Spain. Enferm Infecc Microbiol Clin. 2005;23:194-196.

33. Bonnet JL, de Marigny G, Seigneurin JM. Monosymptomatic form of Rickettsia conori rickettsiosis associated with pure ocular lesions. Bull Soc Pathol Exot Filiales. 1969;62:1006-1011.

34. Restat S, Lenoble P, Nasica X, et al. Mediterranean spotted fever. Apropos of a case. J Fr Ophthalmol. 1999;22:554-561.

35. Suttorp-Schulten MS, Luyendijk L, van Dam AP, et al. Birdshot chorioretinopathy and Lyme borreliosis. Am J Ophthalmol. 1993;115: 149-153.

36. Kuhne F, Morlat P, Riss I, et al. Is A29, B12 vasculitis caused by the Q fever agent? (Coxiella burnetii). J Fr Ophthalmol. 1992;15:315-321.

37. Chang JH, McCluskey PJ, Wakefield D. Acute anterior uveitis and HLA-B27. Surv Ophthalmol. 2005;50:364-388.

38. Chang JH, Wakefield D. Uveitis: a global perspective. Ocul immunol Inflamm. 2002;10:263-279.
Clinical Ophthalmology

\section{Publish your work in this journal}

Clinical Ophthalmology is an international, peer-reviewed journal covering all subspecialties within ophthalmology. Key topics include: Optometry; Visual science; Pharmacology and drug therapy in eye diseases; Basic Sciences; Primary and Secondary eye care; Patient Safety and Quality of Care Improvements. This journal is indexed on Submit your manuscript here: http://www.dovepress.com/clinical-ophthalmology-journal

\section{Dovepress}

PubMed Central and CAS, and is the official journal of The Society of Clinical Ophthalmology (SCO). The manuscript management system is completely online and includes a very quick and fair peer-review system, which is all easy to use. Visit http://www.dovepress.com/ testimonials.php to read real quotes from published authors. 